\title{
What a Difference a Case Makes. A Discourse Study of the Patient's Presence in Contemporary Medical Case Reports
}

\author{
Magdalena Zabielska
}

Adam Mickiewicz University in Poznań, Poland

mzabielska@wa.amu.edu.pl

\begin{abstract}
Ample research on written professional medical discourse across genres and modalities generally points to the impersonal and dehumanising character of the communication in this particular context. On the other hand, there have been numerous attempts at incorporating the human element into medical texts, be it through different models, sets of guidelines, generic varieties, but also, more holistically, models of medical practice. The objective of the present paper is to study the discourse of case reporting in contemporary medical case reports with respect to patient's presence. To this aim, a sample of regular case reports derived from a prestigious medical journal has been examined with particular attention to textual references to the treated. It will be shown that regardless of the current trend in medical practice in the direction to patient-centredness, regular medical reports, i.e. not special varieties, still bear the features of the biomedical discourse.
\end{abstract}

Keywords: medical discourse, case report, patient, textual reference.

\section{Streszczenie}

Opis przypadku nie odchodzi do lamusa. Dyskursywna analiza obecności pacjenta we współczesnych medycznych opisach przypadku

Liczne badania specjalistycznego pisanego dyskursu medycznego, różnych gatunków oraz form, wskazuja na ogólny bezosobowy $i$ dehumanizujacy charakter komunikacji $w$ tym konkretnym kontekście. Z drugiej strony podejmowano liczne inicjatywy uwzględnienia owego ludzkiego pierwiastka $w$ tekstach medycznych, zarówno poprzez różnego rodzaju modele, wskazówki, odmiany gatunkowe, jak również, bardziej holistycznie, poprzez różne modele praktyki medycznej. Celem niniejszego artykutu jest zbadanie dyskursu raportowania przypadków we wspótczesnych opisach przypadków $w$ odniesieniu do obecności pacjenta. $W$ tym celu zanalizowano próbkę typowych opisów przypadków zaczerpniętych z prestiżowego czasopisma medycznego, zwracając uwage na tekstowe odnośniki do osób leczonych. Badanie pokazuje iż regularne opisy przypadku, tj. nie specjalne odmiany, nadal nosza znamiona dyskursu biomedycznego. 
Stowa kluczowe: dyskurs medyczny, opis przypadku, pacjent, odniesienia tekstowe

\section{Introduction}

A case report belongs to written professional discourse and its aim is to describe unknown diseases, their new aspects or anything novel about a specific treatment or drug use. They can function at the institutional level as part of hospital documentation or at the academic level as types of publications. Functionally, case reports can be retrospective and prospective (Vinjamury 2012) or can be used as a classical clinical case report, representing an "interesting and challenging patient encounter" for the expansion of research and knowledge, or a "fact finding tool or clinical vignette", representing "teaching and learning experience" in the context of education (Jenicek 2014: 126-129).

Conceptually, it refers to characteristic routine performance in the medical contexts and helps to discursively construct it at the textual level. "The case records and re-presents the process by which the physician reached a recognisable diagnosis; (...)" (Hunter 1996: 309). More specifically,

[i]t includes the ability to elicit useful information from the patient, perform a good physical examination, order tests with precision and restraint, prescribe efficacious therapy with minimal harm to the patient, and discern and address the psychological, moral, and social problems that may arise in connection with the illness" (Hunter 1996: 310).

In other words, the conceptualisation is both a professional and discursive construct pointing to the centrality of the genre in medicine. Consequently, one of the elements of medical expertise is the so-called "case-expertise", i.e. the knowledge of 'illness scripts' (Schmidt et al. 1990) which allows one to solve a particular case (Greenhalgh 1999: 323), depending on the experience of the medical professional". What is more, "[e]ach case report represents a healthcare encounter involving a real person with a real clinical problem, (...) real-world concerns and experiences" (Jackson 2014). Therefore, the question may arise concerning the portrayal of the patient in contemporary medical case reports with particular reference to a number of attempts which have been made to remedy some of the problems reported in literature so far. 


\section{The discourse of case reports and its problems}

The person responsible for the ultimate transformation of the genre in the nineteenth century into to a form similar to the reports published now was Sir William Osler, whose works were almost half of his publications. He emphasised the role of case reports urging to "[a]lways note and record the unusual.... When you have made and recorded the unusual or original observation... Publish it. Place it on permanent record as a short, concise note. Such communications are always of value" (cf. Coccia and Ausman 1987; Ortega-Loubon and Correa-Márquez 2014: 90). "The act of recording, discussion with colleagues, and publishing our clinical observations with patients remains essential to the art of medicine and patient care". One of the authors of case reports at the end of nineteenth century was also Sigmund Freud, who based them on his private psychoanalytic practice. They combined his own discussions of the problems described as well as patients' accounts, and, to the very author, they seemed more like stories than scientific accounts. This literary character was later continued in a general narrative trend in medical case reporting (Nissen and Wynn 2014; cf. Kasim et al. 2009). Apart from Freud, other eminent researchers who published case reports, contributing knowledge on major diseases: Paul Broca (language impairment), Alois Alzheimer or Frederick Treves (Elephant man) (Kasim et al. 2009).

In contemporary case reports, the author seems "evacuated" (Geertz 1988) while the focus falls on diagnostic procedures and performed treatment. Therefore, as Taavitsainen and Pahta (2000) point out, nowadays, the mode of writing case reports is more detached and impersonal (2000: 72). These results have been also confirmed by Van Naerssen's (1985) study of medical records (a case-based genre, generated for each patient as part of hospital documentation). Among the features of this text type Van Naerssen (1985) mentions apart from specialised vocabulary, abbreviations, but, most importantly for this paper, a low frequency of words directly referring to patients, i.e. the word 'patient' as well as personal and possessive pronouns and/or names. As regards case reports, the fragment with the greatest frequency of patient references is Introduction, in which his/her symptoms are described. However, even here the account is presented either with a doctor slant $\left(3^{\text {rd }}\right.$ person perspective) or is scant (Hurwitz 2006: 235; cf. Van Naerssen 1985: 62-63; Lysanets et al. 2017), often being marked with the words: "the patient complained of...”. The reason of such a state of affairs might be, apart from physicians' lack of time to write lengthy accounts, "a reluctance to contaminate the factually indisputable with the experientially unverifiable" (Macnaughton and Evans 2004: 57). As Macnaughton and Evans (2004) observe, the 
patient's experience in medical records is still something that medical professionals remain unequivocal about. Nevertheless, the fact that medical records have become increasingly accessible to patients in the UK has eradicated some of the value-laden vocabulary contained there and has initiated the debate over the status of the patient's voice in these purely scientific accounts of medical facts (Macnaughton and Evans 2004: 58). Also other studies where the patient's perspective is adopted point to the restricted character of their presence in these texts. Such a state of affairs has been confirmed in Helan's (2012) study of the genre at hand in general as well as in Murawska's (2011: 191-192) and Zabielska's (2014) examinations of patient imaging in medical case reports in particular. This suggests treating a patient as "the object of some disease entity" (Mead and Bower 2000: 1089) or reducing him/her to the disease he/she suffers. It may also lead to other naming practices of this kind used among health professionals (cf. Anspach 1988; Mintz 1992; Siegler 2010). This process is aptly summarised by Hurwitz (2000):

The traditional medical view of the consultation is to see it as an opportunity to fashion a clinical case history. This particular narrative genre consists of a story that begins with a succession of events or experiences relating to the patient, which then becomes progressively abstracted from the patient's control and the context of its original telling. The extracted story progresses, transformed by a medicotechnical vocabulary not likely to be understood by the patient. The patient tends to lose control of the story as the case history develops and becomes a tale that only someone else can tell, taking on a life of its own in staff rounds, case conferences, and the medical literature. Meanwhile, the patient as the person from whom the story originally arose becomes increasingly incidental to it, maintaining within it only the anonymous presence of a ghost.

(Hurwitz 2000: 2088)

Although the authors explicitly refer to the event of medical consultation, which then may be transformed by medical professionals into many other (case-related) genres, the account of the process may also be applied to modern medical case reports, which commence with a few lines describing the reasons of the patient's presentation. Yet, the further the text progresses, from history and physical examination/tests, through treatment, to discussion, the patient as a whole person disappears, giving place to references to his/her body parts or only medical details.

Also in the context of a different genre, the study of methodology sections in descriptive medical-surgical nursing articles, confirms that in terms of word frequencies, the most 
frequently occurring ones are those related to research whereas the ones connected more with healthcare and the ones related to patients were not significant in terms of frequency (Uzun 2016: 73).

In reply to that, some solutions have been proposed, ranging from general observations, through single guidelines (Charon 1986; Donnelly 1988; Delbanco 1992), to whole models to be implemented. However, the first proposals concern other than reports, case-based genres: presentations (oral genre of presentation of medical cases, for instance during ward rounds in hospitals) - Freeman's (1994) patient-centred case presentation; or case records - Weed's (1969) POMR - patient-oriented medical record. Only well after 2000 some attempts to improve the quality of medical case reports have been offered, both structure- and contentwise (McCulloch et al. 2009; Gagnier et al. 2013; Hirst et al. 2013; Agha et al. 2016a, b), introducing particular models, e.g. the CARE (CAse REport) (Gagnier et al. 2013) or The SCARE guidelines (Agha et al. 2016a, b) and the IDEAL framework (McCulloch et al. 2009; Hirst et al. 2013) respectively, with the last two referring exclusively to surgical case reports.

As regards the genre of the case report, one may point to such recent developments as integrated narrative and evidence based case reports (combine the evidence-based story, i.e. medical facts as well as patient's and doctor's accounts, Reis et al. 2002), storied case reports (particularly emphasise the doctor's reworking of the patient's story, Bayoumi and Kopplin 2004), interactive case reports (allow readers to comment on published cases online and feature $1^{\text {st }}$ person narratives by the patient, Smith 2008a; b) or Case challenge (present particularly challenging patient scenarios to be solved by readers, Pregerson 2014), which constitute attempts at integrating the patient's account in various modes and, at the same time, testify to the revived interest in the genre. Yet, although they have attracted significant attention in professional medical journals, they have introduced the patient's perspective only as a complimentary element and have not considered either its merging with the rest of the text (Nissen and Wynn 2014) or the very way the patient is portrayed in the main body of the text written by the doctor.

The above-presented generic innovations can be interpreted as a reflection of recent trends in medical practice, namely the patient-centred perspective (Balint et al. 1970: 25-26) and patient advocacy (Gilkey et al. 2008: 13), which advocate the inclusion of the patient's experience of illness and his/her involvement into the process of diagnosis and treatment respectively. Consequently, at the level of the text, these new medical perspectives can be manifested through including the patient's experience of illness into professional text, i.e. writing what the patient feels (patient-centredness), and inviting him/her to co-construct the 
account, i.e. incorporating his/her text or co-writing it with him/her (patient advocacy). This may be beneficial both to doctors in the development of compassion towards patients, and to patients, who become active participants in the process of diagnosis and treatment, and are not perceived as disease entities that should be managed, which is the case both in the socalled biomedical model of medical practice and its discourse. In this particular approach the patient is viewed as a passive recipient of treatment while the disease as a malfunction of the body that can be repaired (cf. Wade and Halligan 2004: 1398).

\section{Patient's perspective in contemporary medical discourse - a study}

\subsection{Data}

The data for the study constitutes a small corpus of 115 contemporary case reports derived from the prestigious professional medical journal the Lancet. The articles were published in the periods of 1995-1996 and 2009-2012, their length ranged from almost a column of the text to one page and concerned various medical areas. The articles were downloaded from the journal's website. Additionally, the texts from the period between 1995 and 1996 begin with a characteristic address - "SIR" (original spelling) - to the journal's editor.

\subsection{Methods}

The aim of the discursive analysis of the corpus will be to establish the portrayal of the patient in contemporary medical case reports (comparably more patient-focused than other medical genres). Such an analysis was conducted earlier on a smaller number of regular case reports (Zabielska 2014) and the current examination is meant to serve as a continuation of the project. It also refers directly to studies conducted by Francis and Kramer-Dahl (2004) and Bloor (2016) drawing on Systemic Functional Linguistics. What will be studied here will be the linguistic resources referring to the patient (directly or indirectly) and the examples of his/her absence. At this point, an attempt will be made to answer the question of how medical authors place communicative accents in the texts when they describe disease, diagnosis and treatment (thematic-rhematic analysis and transitivity). In detail, do doctors write about the patient as a subject or as an object, e.g. we operated on the patient, the patient was operated on or operation was performed? Do they write about a suffering patient, about the diseased body or only about how the disease is treated, e.g. he experienced the following symptoms..., he had the following symptoms... or In this case, we used the following management... . In other words, the emphasis will be put here on particular language resources indexing patients 
in the texts, e.g. patient, he, woman, or only parts of their bodies, organs, etc., e.g. head, kidney. This way, the parameters adopted in the analysis will address the area of the functionally and cognitively-based grammar of discourse (Halliday 1979; Duszak 1987; Halliday 1994; Smith 2003) as well as genre analysis (Bazerman 1988; Swales 1990; Bhatia 1993). Consequently, this examination will be qualitative in nature (discourse analysis) in order to determine the textual visibility of the patient and its character. What is meant by this visibility is demonstrated below - the many ways of patient reference (patient textual references underlined), on the basis on an interactive case report:

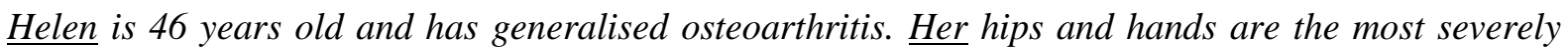
affected joints. Helen's health problems started at the age of 11, following a fall on a cross-country run. She consulted her general practitioner and the accident unit multiple times with increasing levels of pain and disability before she was eventually diagnosed with Perthes disease, a diagnosis

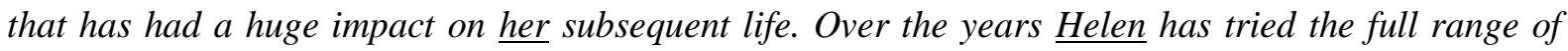
pain medications. A review of her past prescriptions reveals trials of over 15 different analgesics and anti-inflammatory drugs, covering the full range of the analgesic ladder. Her current medication, oxycodone, has so far been the best choice, optimising pain relief whilst minimising side effects. Helen continues to be under the care of replacement. Helen remains independent and self-caring despite deterioration in her levels of pain and physical functioning. $\mathrm{CJ} 4^{1}$

\subsection{Results and discussion}

On the basis of the analysis of patient references in the material at hand, the following scale of patient's presence can be suggested, from the most impersonal to the most patient-centred: (1) patient's absence, (2) patients as cases, (3) patients as locations, (4) patient's profile $-3^{\text {rd }}$ person perspective and verbatim accounts. Additionally, two other aspects related to the presentation of the patient will be referred to, i.e. (5) diseases as 'it' and (6) our patient / us and other perspectives

\subsubsection{Patient's absence}

Under this category of patient indexicality in the reports subsumed are examples which are characterised by complete textual absence of the references to patients. Such fragments may include the following information: presenting complaint - signs and symptoms (1), describing history (2), underwent treatment procedures (3) as well as bodily changes or body

\footnotetext{
${ }^{1}$ The codes at the end of the examples stand for particular texts from the corpus analysed. For a complete list of all the texts which are cited see the Appendix.
} 
parts (4) metonymically standing for the patient. As regards the first theme, the texts may refer to pain or other bodily sensations without the reference to the experiencer, i.e. the patients. This theme is closely connected to the fourth category, i.e. bodily changes and body parts where there is also no reference to the very patient and the body parts referred to as if metonymically stand for them. In this case, it is possible to differentiate between whole/part references, i.e. referring to the patient as a whole person and referents that stand for the patient in the texts. This abstraction from the patient is a good illustration of how Frank (1995) describes patient imaging in professional medical journals, i.e. reduc[ing] to [be] “clinical material" (1995: 12, cf. example 10 in section 3.3.2). One more mode of patient reference (5), or, in fact, their absence is the so-called technology as the agent, as identified by Anspach (1988) in medical case presentations (an oral presentation of a patient during a ward round performed by a doctor or a student). In this variant, an account is given of the results of medical tests in a particularly impersonal mode i.e. as 'revealed', 'showed', 'proven' by particular medical equipment, the so-called "abstract rhethors" (Halloran 1984: 74) or "chart talk" (Mattingly 1998: 274), which "emphasise[s] diagnosis and pathology". In regular case reports, such examples appear most frequently in the Examination section, which gives an account of the patient's current condition, i.e. what the doctor observes as well as the results of medical tests (Murawska 2013; Zabielska 2014).

If this imaging is discussed with reference to the biomedical model (see section 2 above), it can be seen that at the level of the text, it is realised by excluding patient references in chosen fragments and constructing sentences in such a way that they draw readers' attention to the particular manifestation of a given disease entity as well as "medical techniques and therapeutics" (Ashcroft 2000: 288) which aim at its eradication. This imaging is not limited to single sentences but appears also in longer fragments (6) featuring sequences of described diagnostic tests and treatment procedures where not only patients but also those who perform these procedures are textually absent. This contributes to the impersonal character of the studied texts.

(1) There were no other abnormal findings and no focal neurological signs. L38

(2) Medical history included laparoscopic adjustable gastric banding fitted in September, 2008, for class III obesity, when her body-mass index (BMI) was $45 \cdot 4 \mathrm{~kg} / \mathrm{m} 2$. L5 
(3) Antibiotic treatment was started with amoxicillin/clavulanic acid and surgical debridement was done. After surgery, there was rapidly progressive inflammation of the local site and worsening of her general condition. L24

(4) Because the mass was found to be freely mobile in the abdomen, we suspected it was a wandering spleen. L13

(5) Funduscopy showed atrophy of the right optic disc and swelling of the left disc. L31

(6) Cefazolin was started after obtaining blood cultures and stool samples. Febrile episodes continued. Chest radiograph showed a right perihilar infiltrate. The antibiotic was changed to ceftriaxone. Bone-marrow smear revealed dyserythropoiesis; stains for acid-fast bacilli were negative. Fevers continued although all cultures remained negative. A dermatology consultation was obtained to evaluate a 1-0X1-4 cm red, ulcerated, vascular nodule on the right side of his scalp which the family had noted 2 months previously and which had slowly enlarged (figure). L32

\subsubsection{Patient as case}

Moving further on the scale of patient indexicality, there are sentences which feature the word 'case'. As has been already said in the theoretical background, professional medical discourse is primarily used to refer to individual occurrences of particular diseases. Yet, there are examples where this word may also mean 'the patient', which has been viewed by some researchers as an impersonalising device (Matthews and Matthews 2008: 135; McEwen 2009: 103). Whereas the first two authors explicitly state that patients must not be referred to as 'cases', McEwen (2009: 103) extends the definition of 'case' from the meaning of an individual instance of a given disease to a patient's condition including its medical and social repercussions. In the studied corpus, the following examples with the word 'case' have been identified:

(6) A case of acute post-transfusion hepatitis B was reported to our blood bank. L51

(7) We present the case of a 40-year-old woman who was treated for fibromyalgia by a professional acupuncturist. L35

(8) Our patient's case is the first report of nosocomial infection with CCHF virus in India. L27 
(9) Case 1 (14 years old, female, spinal muscular atrophy diagnosed by muscle biopsy at age 1 year, severe generalised weakness, wheelchair-bound). L62

(10) In our material we have diagnosed 194 cases with H heilmannii gastritis since 1988 and one case of gastric cancer, and Yang et al reported one case of cancer among only 51 infected patients. L65

In the examples above, a few variants with the word 'case' can be distinguished - with reference to an individual occurrence of a disease (6) as well as "a case of a patient" (7) and a similar "patient's case" (8), which all, however, do not refer explicitly to the patient as being a 'case', as has been reported in the literature. In contrast, (10) seems rather dehumanising in its mode of reference to a group of patients as 'material' (cf section 3.3.1 above). (9) is also an interesting instance, where a series of two cases contains fragments of telegraphic descriptions.

\subsubsection{Patient as container}

In the below-given examples, the patient is referred to directly and as a whole person, but the perspective is shifted to the object of study while the patient serves as the location of the phenomena described. This mode of patient reference is an example of the metaphor of container (cf. Lakoff and Johnson 1980). Such a construction allows writers to conceptualise patients as locations where diseases are identified and treatment performed. It is a useful linguistic resource to draw attention to the disease at hand, but, at the same time, still maintaining the patient in the 'linguistic view'. It seems relatively frequent in medical texts (Fowler 1996). Elsewhere, the present author demonstrated that in the case of case reports, the mode of presenting the patient with an in-and-out orientation where treatment often means crossing the skin boarder is employed especially in the Discussion section. Here the author of a given publication tries to abstract from a single individual case and to offer a more general view, thus changes the perspective from a given person to the disease against his/her background (Zabielska 2014).

(11) In our patient, there was also hypogonadotropic hypogonadism. L25

\subsubsection{Patient's profile $-3^{\text {rd }}$ person perspective and verbatim accounts}

In this mode of patient presentation, the most commonly appearing in professional medical texts when referring to patients, one deals with $3^{\text {rd }}$ person perspective. In the context of medical case reports, such a mode is characteristic in the account of the patient's presenting complaint and ensuing comment, usually at the beginning of the report (12, compare a similar 
case (1) in the mode of patient's absence in 3.3.1, yet without a patient referent) (Zabielska In press). In (13) and (14) also a particular patient's viewpoint is acknowledged while in (15) a particular account is referred to. Finally, in (16) a direct citation of the patient's expression is given.

(12) The following day she complained of severe headache and shivering; although initially apyrexial she rapidly developed a pyrexia, tachycardia, and deteriorating consciousness. L43

(13) Our patient was desperate to achieve a normal pregnancy. L7

(14) The woman felt angry and misled by publicity highlighting the link between sunlight and skin cancer, since she did not believe it was possible to develop such a lesion in the absence of sun exposure. L63

(15) She also reported nausea and anorexia over the preceding 3-4 months, with postprandial gastro-oesophageal reflux, vomiting on several occasions, recurrent hiccups, and weight loss of about $10 \mathrm{~kg}$. L45

(16) She also reported new-onset "coke-coloured" urine. L14

It needs to be noted, however, that the instances of the last variant, i.e. exact words, are rather rare and, bearing in mind the scale of patient presentation, the patient-centred discourse in the context of medical case reports means primarily examples such as (12) or (15) where the patient's account is just reported.

\subsubsection{Disease as 'it'}

The two following modes cannot be classified strictly as of patient presentation, yet the aspects they refer to are connected with what this presentation concerns. Disease as 'it' refers to the typical way in which diseases are portrayed in medical texts, including case reports. It stands for conceptualising diseases as things, which allows the writer to talk about "having diseases" (17-18) or enumerating them as if they were objects (19). Such a mode of reference contributes also to the perception of the condition as if it was a separate entity that can be eradicated from the body as opposed to some malfunction of the way the body performs (cf. Pasveer 1989). For Blois (1984), this mode of reference can be called nominalist as opposed to the psychological one, where the disease is presented as a condition experienced by a 
patient. At the sentence level, this difference can be seen when comparing such constructions 'I have... (a disease)' and 'I suffer from... (a disease)' (Staiano 1986), corresponding to the nominalist and psychological modes of presentation respectively.

(17) Our patient had a large subocclusive eustachian valve at the IVC-right atrium junction. L6

(18) He had an 8-day history of cough, throat pain, and fever and was referred to our intensive care unit for bronchial arteriography. L9

(19) In May, 2010, a 50 year-old man presented to us with a 10 day history of abdominal pain, fever, and shivering with elevated $C$ reactive protein and leucocytes. L28

\subsubsection{Our patient / us and other perspectives}

The other aspect related to the modes of patient presentation are traces of others, i.e. textual references to other people 'being present' in the texts analysed. On the hand, these are words marking the presence of the very authors of the article, i.e. personal (20 and 22) and possessive pronouns (21). The presence of these references seems to contribute to the effect of limiting the distance between the doctor and the patient as well as creating some form of solidarity with the treated. In other words, the patient does not seem to be treated by faceless medical technology, giving account of the results of medical tests in the impersonal mode. It is a doctor, who, though represents medicine, co-constructs the narrative with the patient. In (23), the observation of a patient's family member is offered, which constitutes an additional contribution to the communication in the doctor-patient dyad.

(20) In April, 2011, a 32-year-old woman presented to us with a 5-day history of pain in the upper left side of her abdomen. L13

(21) Our patient made a successful recovery after surgery and all biochemical markers returned to normal. L18

(22) We made the provisional diagnosis of angio-oedema, and our patient was given dimetindenmaleat $4 \mathrm{mg}$ intravenously. L29

(23) The patient's wife had noticed that on occasion his right ear was red, hot, and swollen for several days, either associated with redness in the eyes or independently. L17 


\section{Conclusion}

In this paper, an attempt has been made to examine patient's presence on the basis of a small corpus of contemporary medical case reports derived from the prestigious medical journal the Lancet. In detail, textual references to the treated as well as their absence have been inspected with a view to establishing their character and its effect on patients' image in this professional medical genre. This aspect was discussed against the background of the biomedical model of medical practice and alternative models as well as the nature of professional medical discourse in general, the practice of working up a case and the discourse of case reporting in particular. The study shows that regardless of the current trend in the direction to patient-centredness, regular medical reports, i.e. not special varieties, still bear the features of the biomedical discourse. This has been demonstrated on the basis of a scale by means of which patient's presence can be described and analysed. This scale consists of different types of textual references marking the patient's presence as well as types of their absence. Additionally, two other aspects related to this presence has been identified. Concluding, though functioning in a relatively different, i.e. more patient-centred context, contemporary medical case reports still feature a discourse about "mindless bodies, depersonalised behaviours, and fragmentary body parts" (Crites 1966, as quoted in Hurwitz 2006:229).

\section{Appendix}

CJ4 Richardson, Jane C., Christian D. Mallen, Helen S. Burrell (2008) “A Woman Living with Osteoarthritis: A Case Report.” Cases Journal 1 (153). http://www.casesjournal.com/content/1/1/153.

L5 Czapran, Adam, Martin Doherty, Angela Haddon, Mourad Labib (2012) "Recurrent Aspiration and Upper Lobe Cavitation." The Lancet 379; 92.

L6 Berardi, Sonia, Annalisa Berzigotti, Alberta Cappelli, Marianna Mastroroberto, Carla Serra, Antonia D’Errico, Vincenzo Russo, Angeles Garcia-Criado, Claudia Sama (2011) "Routine Blood Tests? Helping You Live(r) Longer!” The Lancet 378; 2048.

L7 Fisher, Rosemary A., Stuart A. Lavery, Anna Carby, Shadi Abu-Hayyeh, Rebecca Swingler, Neil J. Sebire, Michael J. Seckl (2011) “What a Difference an Egg Makes.” The Lancet 378; 1974. 
L9 Boissier, Florence, Antoine Khalil, Ludivine Chalumeau-Lemoine, Francois-Xavier Lescure, Antoine Parrot (2012) "Rash Diagnosis of Blood Expectoration.” The Lancet $379 ; 1170$.

L13 Somalwar, Ashutosh M., Jitendra P. Bhagat, Chetan D. Rathi (2011) "I Wonder What the Mobile Mass Is?" The Lancet 378; 1604.

L14 Cheng, Henry G., Caitlin Gomez, Sarah Khan, Soma Wali (2011) “A Purple Rash.” The Lancet 378; 1526.

L17 Roux, Charles, Stéphanie Guey, Isabelle Crassard, Charlotte Hautefort, Frédéric Lioté, Eric Jouvent (2011) “A Rare Cause of Gait Ataxia.” The Lancet 378; 1274.

L18 Brunel, Valéry, Bruno Cauliez, Laurence Lacaze, Ghassan Riachi, Gilles Gargala, Francois Arnaud, Alain Lavoinne, Michel Scotté (2011) "Liver Mass in a Young Adult." The Lancet 378; 1196.

L24 Preiswerk, Benjamin, Inja B. Allemann, Marco Maggiorini, Véronique Müller (2011) "From a Pimple to a Crater." The Lancet 378; 1402.

L25 Van Durme, Caroline M. P. G., Jérôme M. H. Kisters, Pieter Van Paassen, Ronald W. Van Etten, Jan Willem Cohen Tervaert (2011) “Multiple Endocrine Abnormalities.” The Lancet 378; 540.

L27 Mishra, Akhilesh C., Minesh Mehta, Devendra T. Mourya, Sudhir Gandhi (2011)

“Crimean-Congo Haemorrhagic Fever in India.” The Lancet 378; 372.

L28 Khodakaram, Kaveh, Neshro Barmano (2011) "Uncommon Reaction to a Common Prescription." The Lancet 378; 288.

L29 Gutermuth, Jan, Korinna Nadas, Michael Zirbs, Florian Seifert, Rüdiger Hein, Johannes Ring, Knut Brockow (2011) “Papular-purpuric Gloves and Socks Syndrome.” The Lancet $378 ; 198$.

L31 Nishioka, Tatsuya, Akinori Kondo, Kenji Suga (1995) "Progressive Blurring of Vision in Both Eyes." The Lancet 346; 1402.

L32 Malane, Michelle S., Teresita A. Laude, Chun Kuo Chen, Senih Fikrig (1995) “An HIV1-positive Child with Fever and a Scalp Nodule.” The Lancet 346; 1466.

L35 Halvorsen, T. B., S. S. Anda, A. B. Naess, O. W. Levang (1995) "Fatal Cardiac Tamponade after Acupuncture through Congenital Sternal Foramen.” The Lancet 345; 1175 .

L38 Haworth, Fiona L. M., G. C. Cook (1995) “Needlestick Malaria.” The Lancet 346; 1361. L43 MacConnell, Thomas. J., Albert Ferro (1995) “A Sore Eye and Meningitis.” The Lancet $346 ; 1269$. 
L45 Read, Stephen J., Barbara A. Leggett, Michael P. Pender (1995) “Gastroparesis with Multiple Sclerosis." The Lancet 346; 1228.

L51 Elghouzzi, Marie H., Anne M. Couroucé, Magnius Lars O., Lunel Francoise, Lapierre Valerie (1995) “Transmission of Hepatitis B Virus by HBV-negative Blood Transfusion.” The Lancet 346; 964.

L62 Bruce, A. K., E. Jacobsen, H. Dossing, J. Kondrup (1995) "Hypoglycaemia in Spinal Muscular Atrophy." The Lancet 346; 609-610.

L63 Williams, Hywel C. (1995) "Melanoma with no Sun Exposure.” The Lancet 346; 581. L65 Morgner, A., E. Bayerdourffer, A. Meining, M. Stolte, G. Kroher (1995) "Helicobacter Heilmannii and Gastric Cancer." The Lancet 346; 511-512.

\section{References}

Agha, Riaz A., Alexander J. Fowler, Alexandra Saetta, Ishani Barai, Shivanchan Rajmohan, Dennis P. Orgill (2016a) “A Protocol for the Development of Reporting Criteria for Surgical Case Reports: The SCARE Statement.” International Journal of Surgery 27; $187-189$.

Agha, Riaz A., Alexander J. Fowler, Alexandra Saetta, Ishani Barai, Shivanchan Rajmohan, Dennis P. Orgill (2016b) “The SCARE Statement: Consensus-based Surgical Case Report Guidelines.” International Journal of Surgery 34; 180-186.

Anspach, Renee R. (1988) "Notes on the Sociology of Medical Discourse: The Language of Case Presentation.” Journal of Health and Social Behaviour 29; 357-375.

Ashcroft, Richard E. (2000) “Teaching for Patient-centred Ethics.” Medicine, Health Care and Philosophy 3; 287-295.

Balint, Michael, John Hunt, Dick Joyce, Marshall Marinker, Jasper Woodcock (1970)

Treatment or Diagnosis: A Study of Repeat Prescriptions in General Practice. London: Tavistock.

Bazerman, Charles (1994) "Systems of Genres and the Enactment of Social Intentions." [In:] Aviva Freedman and Peter Medway (eds.), Genre and the New Rhetoric. London: Taylor \& Francis Publishers; 105-123.

Bhatia, Vijay K. (1993) Analysing Genre: Language Use in Professional Settings. London: Longman.

Blois, Marsden S. (1984) Information and Medicine. Berkeley: University of California

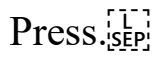


Bloor, Meriel (2016) "The Construal of Terminal Illness in Online Medical Texts: Social Distance and Semantic Space.” [In:] Sheena Gardner and Sian Alsop (eds.), Systemic Functional Linguistics in the Digital Age. Equinox eBooks Publishing; 120-133.

Charon, Rita. 1986. “To Render the Lives of Patients.” Literature and Medicine 5; 58-74. Coccia C. T., J. I. Ausman (1987) "Is a Case report an Anecdote? In Defense of Personal Observations in Medicine." Surgical Neurology 28 (2); 111-113.

Crites, Stephen (1966) "Religion as Story: Angels We Have Heard.” [In:] Robert Scholes and Robert Kellogg (eds.), The Nature of Narrative. Oxford: Oxford University Press; $23-63$.

Delbanco, Thomas L. (1992) "Enriching the Doctor-patient Relationship by Inviting the Patient's Perspective.” Annals of Internal Medicine 116; 414-418.

Donnelly, William J. (1988) "Righting the Medical Record. Transforming Chronicle into Story." The Journal of American Medical Association 260 (60); 823-826.

Duszak, Anna (1987) The Dynamics of Topics in English and Polish. Warszawa: Wydawnictwa UW.

Fowler, Roger (1996) Language in the News: Discourse and Ideology in the Press. London: Routledge.

Francis, Gill, Anneliese Kramer-Dahl (2004) "Grammar in the Construction of Medical Case Histories.” [In:] Caroline Coffin, Ann Hewings and Kieran O’Halloran (eds.), Applying English Grammar. Functional and Corpus Approaches. London: Hodder Education; 172-190.

Frank, Arthur (1995) The Wounded Storyteller: Body, Illness, and Ethics. Chicago: The University of Chicago Press.

Freeman, Thomas R. (1994) “The Patient-centred Case Presentation.” Family Practice 11; $164-170$.

Gagnier, Joel, Gunver Kienle, Douglas Altman, David Moher, Harold Sox, David Riley et al. (2013) "The CARE Guidelines: Consensus-based Clinical Case Reporting Guideline Development." Global Advances in Health and Medicine 2; 38-43.

Geertz, Clifford (1988) Words and Lives: The Anthropologist as Author. Palo Alto, Calif.: Stanford University Press.

Greenhalgh, Trisha (1999) "Narrative based medicine in an evidence based world." British Medical Journal 318; 323-325.

Gilkey, Melissa B., Jo-Anne L. Earp, Elizabeth A. French (2008) "What is Patient Advocacy?” [In:] Jo-Anne L. Earp, Elizabeth A. French and Melissa B. Gilkey (eds.), 
Patient Advocacy for Health Care Quality: Strategies for Achieving Patient-centred Care. Boston: Jones and Bartlett Publishers; 3-28.

Francis, Gill, Anneliese Kramer-Dahl (2004) "Grammar in the Construction of Medical Case Histories.” [In:] Caroline Coffin, Ann Hewings and Kieran O’Halloran (eds.), Applying English Grammar. Functional and Corpus Approaches. London: Hodder Education; 172-190.

Halliday, Michael A. K. (1979) Language as Social Semiotic. The Social Interpretation of Language and Meaning. London: Edward Arnold.

Halliday, Michael A. K. (1994) An Introduction to Functional Grammar. London: Edward Arnold.

Helán, Robert (2012) Analysis of published medical case reports: Genre-based study. [Unpublished Ph.D. dissertation, Masaryk University.].

Hirst, Allison, Riaz A. Agha, David Rosin, Peter McCulloch (2013) "How Can We Improve Surgical Research and Innovation?: The IDEAL Framework for Action." International

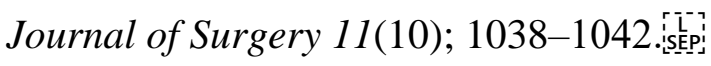

Hunter, Kathryn Montgomery (1996) "Narrative, Literature, and the Clinical Exercise of Practice Reason." The Journal of Medicine and Philosophy 21; 303

Hurwitz, Brian (2000) “Narrative and the Practice of Medicine.” The Lancet 356; 2086-2089.

Hurwitz, Brian (2006) "Form and Representation in Clinical Case Reports." Literature and Medicine 25 (2); 216-240.

Jackson, Debra (2014) “Telling Our Stories of Practice through the Genre of the Case Report." Clinical Case Reports 2; 65.

Jenicek, Milos (2014) Writing, Reading and Understanding in Modern Health Sciences. Medical Articles and Other Forms of Communication. London: CRC Press.

Kasim, N. H. A., B. J. J. Abdullah, J. Manikam (2009) “The Current Status of the Case Report: Terminal or Viable?" Biomedical Imaging and Intervention Journal 5; e4.

Lakoff, George, Mark Johnson (1980) Metaphors We Live by. Chicago: Chicago University Press.

Macnaughton, Jane R., Martyn H. Evans (2004) “Medical Humanities and Medical Informatics: An unlikely alliance? Is there a role for patients' voices in the modern case record?" Medical Humanities 30 (2); 57-58.

Matthews, Janice R., Robert W. Matthews (2008) Successful Scientific Writing. Cambridge: Cambridge University Press.

Mattingly, Cheryl (1998) "In Search of the Good: Narrative Reasoning in Clinical Practice.” 
Medical Anthropology Quarterly 12 (3); 273-329.

McCulloch, Peter, Douglas G. Altman, W. Bruce Campbell, David R. Flum, Paul Glasziou, John C. Marshall et al. (2009) "No Surgical Innovation without Evaluation: The IDEAL Recommendations." The Lancet 374 (9695); 1105-1112.

McEwen, Irene (2009) Writing Case Reports. How to Manual for Clinicians. Alexandria, Va.: American Physical Therapy Association.

Mead, Nicola, Peter Bower (2000) "Patient-centredness: A Conceptual Framework and Review of the Empirical Literature." Social Science \& Medicine 51; 1087-1110.

Mintz, David (1992) "What's in a Word? The Distancing Function of Language in Medicine." Journal of Medical Humanities 13; 223-233.

Murawska (Zabielska), Magdalena (2011) "From a Complaint through Therapy to Recovery: Patient Indexicality in Medical Case Reports.” [In:] Mirosław Pawlak and Jakub Bielak (eds.), New Perspectives in Language, Discourse and Translation Studies. Berlin: Springer; 189-199.

Murawska (Zabielska), Magdalena (2013) “The Tests Confirmed..., the Scan Showed... - a Discourse Analysis of the Examination/Tests and Treatment Sections of Medical Case Reports." [In:] Anna Szczepaniak-Kozak and Hadrian Lankiewicz (eds.), The Creative Potential of a Word: From Fiction to Education. Piła: Wydawnictwo PWSZ im. S. Staszica w Pile; 105-121.

Nissen, Trygve, Rolf Wynn (2014) “The Clinical Case Report: A Review of its Merits and Limitations." BMC Research Notes 8; 264-270.

Ortega-Loubon, Christian, Ricardo Correa-Márquez (2014) “Writing a Case Report: A Work of Art.” International Journal of Medical Students 2 (3); 90-91.

O’Halloran, S. Michael (1984) “The Birth of Molecular Biology: An Essay in the Rhetorical Criticism of Scientific Discourse." Rhetoric Review 3; 70-83.

Pasveer, Bernike (1989) "Knowledge of Shadows: The Introduction of X-ray Images in Medicine.” Sociology of Health and Illness 11 (4); 360-381.

Pregerson, Brady D. (2014) "Ear Pain and a Rash in a 24-year-old Man." Medscape 28 Oct. http://reference.medscape.com/viewarticle/833922?src=emed_case_nl_0\&uac=236 437CX\&impID $=847079 \& \mathrm{faf}=1$.

Reis, Shmuel, Doron Hermoni, Pnina Livingstone, Jeffrey Borkan (2002) "Interactive Narrative and Evidence based Case Report. Case Report of Paroxysmal Atrial Fibrillation and Anticoagulation.” British Medical Journal 325; 1018-1020. 
Schmidt, H. G., G. R. Norman, H. A. P. Boshuizen (1990) “A Cognitive Perspective on Medical Expertise: Theory and Implications.” Academic Medicine 65 (10); 611-621.

Siegler, Eugenia L. (2010) “The Evolving Medical Record.” Annals of Internal Medicine, 153; 671-677.

Smith, Carlota S. (2003) Modes of Discourse. The Local Structure of Texts. Cambridge: Cambridge University Press.

Smith, Richard (2008a) "Why Do We Need Cases Journal." Cases Journal 1 (1). http://www.casesjournal.com/content/1/1/1.

Smith, Richard (2008b) “The Policies of Cases Journal.” Cases Journal 1 (2). http:// www.casesjournal.com/content/1/1/2.

Staiano, Kathryn Vance (1986) Interpreting Signs of Illness. A Case Study in Medical Semiotics. Berlin: Mouton de Gruyter.

Swales, John (ed). 1985. Episodes in ESP. Oxford: Pergamon Press.

Van Naerssen, Margaret M. (1985) “Medical Records: One Variation of Physicians' Language.” International Journal of the Sociology of Language 5; 43-73.

Taavitsainen, Irma, Päivi Pahta (2000) “Conventions of Professional Writing: The Medical Case Report in a Historical Perspective.” Journal of English Linguistics 28 (1); 60-76.

Uzun, Kutay (2016) “A Genre Analysis of the Methodology Sections of Descriptive Medical Surgical Nursing Articles.” Journal of Computer and Education Research 4 (7); 65-81.

Vinjamury, S. Prasad (2008) “Writing a Case Report." The American Acupuncturist 59 (Spring); 18-19.

Wade, Derick T., Peter W. Walligan (2004) "Do Biomedical Models of Illness Make for Good Healthcare Systems?” British Medical Journal 329; 1398-1401.

Weed, Lawrence L. (1969) Medical Records, Medical Education and Patient Care: The Problem-oriented Medical Record as a Basic Tool. Cleveland, Ohio: Press of Case Western University.

Zabielska, Magdalena (2014) Searching for the Patient's Presence in Medical Case Reports. Frankfurt am Main: Peter Lang.

Zabielska, Magdalena (In press) ““"Polishing Gems” - New Generic Developments in the Varieties of Medical Case Reporting and Their Discourse." Tekst i Dyskurs - Text und Diskurs. 